CATALAN REVIEW

Catalan Review

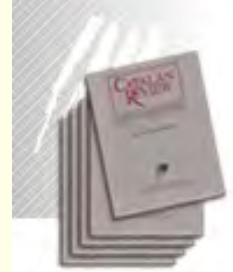

You are accessing the Digital Archive of the Catalan Review Journal.

By accessing and/or using this Digital Archive, you accept and agree to abide by the Terms and Conditions of Use available at http://www.nacs-

catalanstudies.org/catalan review.html

Catalan Review is the premier international scholarly journal devoted to all aspects of Catalan culture. By Catalan culture is understood all manifestations of intellectual and artistic life produced in the Catalan language or in the geographical areas where Catalan is spoken. Catalan Review has been in publication since 1986.
NORTH

AMERICAN

CATALAN

SOCIETY
Esteu accedint a l'Arxiu Digital del Catalan Review

A l' accedir i / o utilitzar aquest Arxiu Digital, vostè accepta i es compromet a complir els termes i condicions d'ús disponibles a http://www.nacs-

catalanstudies.org/catalan review.html

Catalan Review és la primera revista internacional dedicada a tots els aspectes de la cultura catalana. Per la cultura catalana s'entén totes les manifestacions de la vida intel lectual i artística produïda en llengua catalana o en les zones geogràfiques on es parla català. Catalan Review es publica des de 1986.

Les dades de La flexió verbal en els dialectes catalans d' A.M. Alcover i F. de B. Moll. Una aproximació sòciolingüística Maria Pilar Perea

Catalan Review, Vol. XV , No. 1 (2001), p. 53-78 


\title{
LES DADES DE LA FLEXIÓ VERBAL \\ EN ELS DIALECTES CATALANS \\ D'A. M. ALCOVER I F. DE B. MOLL. \\ UNA APROXIMACIÓ SOCIOLINGÜÍSTICA
}

\author{
MARIA PILAR PEREA
}

\section{INTRODUCCIÓ}

La flexió verbal en els dialectes catalans és un recull sistemàtic relatiu a la morfologia verbal dialectal que es basa la integració de dos esforços complementaris: d'una banda, d'un treball de camp ampli i complet realitzat per Antoni M. Alcover a través de diverses eixides filològiques; d'una altra, d'un treball posterior de recopilació i agrupació sistemàtica de les dades obtingudes en les diverses localitats enquestades dut a terme per Francesc de Borja Moll. Els resultats parcials d'aquest treball van aparèixer en quatre números de l'Anuari de l'Oficina Romànica de Lingüística i Literatura. Posteriorment, els mateixos materials es publicaren de manera monogràfica en quatre fascicles editats per les Publicacions de l'Oficina Romànica, que presentaven, en 368 pàgines, els seixanta-set verbs enquestats a cent quarantanou localitats del domini linguístic català. Dos treballs recents (Perea Complements; Compleció) han presentat aquestes dades verbals completades, ${ }^{1}$ reordenades $\mathrm{i}$ complementades amb altres informacions que apareixen en diversos quaderns de camp que Alcover utilitzà per registrar els resultats de les seves enquestes. Tots dos treballs, però, per raó de la seva temàtica, no s'endinsen en els aspectes metodològics que Alcover va aplicar en la seva tasca enquestadora ni en els aspectes sociolingüístics que d'una manera més o menys sistemàtica afloren en les dues fonts d'informació més completes que es posseeixen en relació amb aquest projecte: els dietaris que conté el Bolletí del Diccionari de la Llengua Catalana (d'ara endavant BDLC) i la sèrie de dotze quaderns de camp que recullen la transcripció del conjunt de les dades verbals -cf. Perea (Complements). ${ }^{2}$

1 Aquesta compleció ha permés de recuperar, a partir de les dades de primera mà que forneixen els quaderns de camp, els materials corresponents a un cinquê volum inèdit que contenia la flexió dels verbs reunits sota l'epigraf de verbs especials. Es tractava de la continuació del verb tenir i de la flexió completa dels verbs pondre, romandre, vaig (auxiliar), venir, veure, viure $i$ voler.

2 Les llibretes s'identifiquen amb sigles: Perea (1999a,c): d'una banda, els quaderns de Schädel, Katalanische verbalflexion (QCSchi), Die Katalanischen Dialekte der Ostpyrenäen (QCSch2); d'una altra, la resta de quaderns que inclouen la flexió comple- 
Aquest article es proposa de destacar determinats factors sociolingüístics ${ }^{3}$ que van incidir en el procés d'obtenció de les dades verbals i que van contribuir a atorgar a les variants morfològiques, fonològiques i fonètiques que configuren els materials recopilats per Alcover la seva fesomia característica segons la seva ubicació geogràfica.

Centrades principalment en l'àmbit rural, tot i que els resultats verbals també afecten algunes zones urbanes, les enquestes d'Alcover encaixen de ple en els paràmetres de la dialectologia tradicional. Tanmateix, la consulta dels diversos dietaris posa de manifest certes problemàtiques que en alguns casos esdevenen temes recurrents. Aquestes problemàtiques se centren en dos àmbits: d'una banda, en el conjunt de variables socials que poden afavorir la variació lingüística; d'una altra, en el conjunt d'actituds lingüístiques que poden induir els parlants a un ús determinat de la llengua i que tenen obviament repercussions lingüístiques. En el primer àmbit s'inclouen les variables socials relatives a l'edat, al sexe, a la classe social i al nivell d'instrucció dels informants. El segon àmbit recull actituds com ara la identitat i la consciència lingüístiques, l'autoestima i el prestigi. En relació amb el prestigi, cal considerar també la influència de l'estàndard o d'una altra llengua preeminent sobre les diferents varietats dialectals parlades. També és un factor destacable el grau de castellanització de la societat de l'època. Amb tot, no es pot oblidar que les observacions consisteixen en alguns casos en mers apunts, per la qual cosa la informació pot resultar asistemàtica i incompleta, composta de vegades de notes soltes relatives a algunes de les temàtiques esmentades.

$\mathrm{La}$ incidència de determinades variables socials i de certes actituds lingüístiques, registrades a partir de diversos comentaris d'Alcover, és consignada en els apartats que es desenvolupen a continuació.

\section{LES VARIABLES SOCIALS}

\section{La variable edat}

Entre les diverses variables extralingüístiques que podien provocar variació foneticofonològica i morfològica en les dades verbals recollides per Alcover cal situar en lloc prioritari l'edat que, per opció explí-

ta de tots els verbs que apareixen a La flexió verbal: Conjugació 1 (QCi), Conjugació IJ (QC2), Conjugació III (QC3), Conjugació IV (QC4), Llibreta V (QC5), Quadern VI (QC6), Quadern VII (QC7), Volum VIII (QC8), Llibreta IX (QC9), Llibreta X (QCro).

3 S'obvia en aquest treball l'examen dels aspectes metodològics aplicats a l'enquesta dialectal, com ara la figura de l'enquestador, la selecció dels informants o el métode d'elicitació de les respostes, que seran tractats en una altra avinentesa. 
cita de l'enquestador, determinà, en la majoria de casos, l'elecció de subjectes d'una mitjana d'edat que oscil-lava entre els ro i els 14 anys. L'enquesta sobre la flexió verbal anava destinada principalment a joves $i$ infants, per bé que es recorre a adults $i$ a vells en determinades ocasions, de manera que en alguns casos es poden establir comparacions entre les diverses franges d'edat. La variable edat, doncs, condiciona determinades respostes i és un indicador de la variació i de l'evolució lingüistiques, tant des d'un punt de vista fonètic com morfològic.

El BDLC i els diversos quaderns de camp recullen quatre menes de realitzacions:

a) En primer lloc, les realitzacions que són pròpies del joves de manera exclusiva. Així, a Vilafranca del Penedès els nois tenen tendència a fer [e] la - $a$ àtona, sobretot a final absolut de mot: “ ...s'aprecia entre els nois una tendència ben marcada a fer [ie] o [ie] i [aßße] o $[a \beta \varepsilon]$ les desinències -ia -ába ([buKíe], [buKiríc], [anáße])" (BDLC, X, 228), A València, segons el BDLC (X, 192), es conserven els infinitius [bóldre] (voler) i [pódre] (poder), el darrer només els nens. La mateixa font constata que a Benigànim "el jovent i els que no són gaire de Benigànim la -a la fan [o]: par[5́]qui[o], n[1]n[o], [dóno], [askślo], [míso], [séndro], [téro] [séro]" (BDLC, X, I85).

b) En segon lloc, les realitzacions pròpies dels vells. Segons el $\mathrm{QC}_{4}$, a Organyà, "les formes d'imperatiu i subjuntiu en [-gam] i $[-\mathrm{gaw}]$ i en indicatiu en [-am], [-aw] són característiques dels vells i pagesos". D’altra banda, el QCi indica que, pel que fa a la morfologia de Mieres, "la gent granada usen la forma: [-ísəs], [-ísəm], [-ísəw], [-ísən]". ${ }^{4}$ Cal tenir en compte també l'observació inclosa en el QCio en relació amb l'ús del perfet simple a Sant Hilari Sacalm: "...els vells encara usen de vegades aquest pretèrit". 5

La diferència té novament bases morfològiques en el cas de Tossa de Mar. El QCi recull: "Fan els imperatius en -us (-os) negatiu, no [kájyus], no baxus!, no digus!, no't mogus! no corrus! Però ja només són els vells que ho fan. Hi ha gent vella que encara fa la forma simple del perfet: [onácene], férem, diguérem". El mateix quadern regis-

$4 \mathrm{Cal}$ considerar, però, el següent comentari del quadern (QCI) en relació amb la idoneitat de l'informant: "Férem l'estudi de la conjugació de Mieres just amb Mn. Joaquim Bover, que hi nasqué, i regoneix que allà els nois se diferencien dels vells en la manera de pronunciar, especialment de fer el subjuntiu en -i, que els nois los hi fan i els granats no, i l'optatiu en -esis, -isis. Sospitam que a Mn. Bover li passaren per alt qualques formes característiques i indigenes de la conjugació de Mieres, d’on ell falta fa molts d'anys".

5 I afegeix: "Que es tenga en compte pels altres verbs". 
tra, ara en relació amb Blanes, i amb l'adjunció d'una variable socioeconòmica, que "Els mariners vells diuen: Subjuntiu: bolan ka jo hi baju, bajus, baju, bolien ka tu nesus, nesum, nesu, nesun, bolen que jo kantu, kantus, kantu, kantun, bolien que tu kəntesus, kantesum, kantesu, kantesun. ${ }^{6}$ També diuen els vells: [kantesəs], [-esəm], [-esən]".

c) En tercer lloc, les realitzacions contrastives, ès a dir, les que denoten una diferenciació més marcada entre la parla dels vells i la parla dels joves i infants, $i$ que incideixen tant en aspectes fonètics com morfològics. Així, a Girona, el QCi remarca que "Se nota, com pertot, la diferència entre la pronúncia dels joves (nois) i dels granats o vells. Els joves tanquen més la [-2], sembla francament una $[-e]$ a final de frase fonètica. Els granats la fan casi sempre casi [-ə] amb punta de [-e]”".

A Vinaròs "l'imperfet, en la ra i za persona del singular, el jovent el fa acabar en [áve], [ie] ([io anăve], tu [anáves], ell [anáve], [io preníz], tu [preníes], ell [preníc]). La gent gran que han tingut contactes fora de Vinaròs les fan acabar en [áva], [ía] ([io anáva], tu [anáves], ell [anáva], [io sentía], tu [sentíes], ell [sentía]). El jovent diu: [io fée], tu [fées], ell [fée] io [dúje], tu [dújes], ell [dúje]. La gent gran: [io féə], tu [fées], ell [fée]; io [dúja], tu [dújes], ell [dúje] (BDLC, X, 210)".

El $\mathrm{QC}_{2}$ indica que a Pego, la [-o] de les formes verbals és molt nasal. "De vegades sona [-a] molt fosca, casi com 'o'. Els xics, com més xics són, més la fan [-o]. Els grans $i$ les persones majors, cultes, fan la -’a lleugerament [-a], perquè dissimulen l'accent per no cridar l'atenció dels externs. Les formes [-am], [-aw] (ra i za plural del subjuntiu) són característiques dels vells i gent granada; les [-em], [-ew], ho són del jovent".

Novament, el $\mathrm{QC}_{1}$ constata a Amer les diferències fonètiques entre les realitzacions dels joves i dels vells: "Aquí també els nois tenen una pronúncia diferent dels granats. Aqueis no tanquen tant la $[-2]$, just la fan amb punt de [-e]. Els nois la fan [-e] ben franca a final de frase fonètica. La desinència [-u] de la primera persona de l'indicatiu és importada; la indigena és [-uk] i qualque mica [-ut]". D'altra banda, "lo subjuntiu en [-i] i l'optatiu en -isis, -essis (za persona) domina absolutament, no romanent rastre de [a], [es], [isəs] (...) els joves usen la forma $-i,-i s$ de subjuntiu. Els vells usen la forma: [ísəs], [ísəm], [ísəw], [ísən]".

El QC6 fa notar que al Pont de Suert hi ha també diferències entre la parla de joves i vells en relació amb el condicional: "Feta la conjugació del Pont de Suert amb els minyons i mossetes de la llista, parlant-ne dins ca lo barber Mtre. Toló i Molí, a un li ha escapat la forma ell no tor-

6 Aixi, algunes persones del present i de l'imperfet de subjuntiu de beure es conjuguen: [béyu], [béyus], [béyu], [béyun], [bəyésus], [bəyésum], [bəyésu], [bəyésun]. 
navi mai més, He demanat a tots el que hi havia allà, homes granats, nadius d'aquí, si feien lo condicional així: tu tornaris, el tornari, ells tornarin i m'han dit que si, que tant fan is, in, com-ies, -ien. La forma primera la fan els vells, els granats, quan no se n'adonen. La gent tenral si els hi criden l'atenció, fan la segona. Per lo mateix pertoca afegir a la conjugació del Pont de Suert aqueixa varietat del condicional: $-i s,-i,-i n^{\prime \prime}$.

A Terrassa, es poden detectar tres comportaments diferents en relació amb el verb néixer: "el participi de pretèrit nat, que usen els vells encara; [nəJút], que usen els infants; [nəskút], que usen els altres, la generalitat de la gent" (BDLC, XII, I8).

Quant a Pradell de Sió, el QC6 recull que "els imperfets en [ißßz],

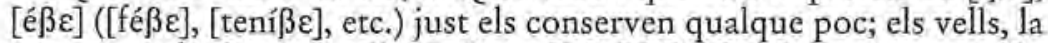
gent granada. La jovenalla els fa en [íe], [éje]. No hi és entrat gota lo subjuntiu $[-\mathrm{i}]$ ".

Igualment, segons el BDLC (X, I72), a la Vila Joiosa "la gent gran demostra una gran preferència per la primera i la za persones del plural del subjuntiu en -gam i en -gau ([koneyám], [koneyáw]); mentre que el jovent les fa en -guem, -gueu ([koneyém], [koneyéw])".

La comparació entre les franges d'edat manifesta l'acció implacable del canvi lingüístic. A Binissalem, "hi està prou introduit, sobretot entre el jovent, el subjuntiu [-i], [-is], [-in]: [uázi] (vazis), [vázis], [vázin], mentre que la gent garrida diu ordinàriament [vázōe], [vázəs], [vázən]" (BDLC, XI, 54). El mateix ocorre a Son Servera: "s'introdueix entre el jovent el subjuntiu [-i]: [vólən caj vézi] (vagi), [vézis] (vagis), [vézin] (vagin); els granats i més els vells diuen casi sempre: [vólan kəy vézə], [vézəs], [vézaən]” (BDLC, XI, 38 ).

De la mateixa manera, pel que fa a la variació en l'imperfet de subjuntiu, a la Vila d'Eivissa "a l'imperfet de subjuntiu, sobretot en la jovenea, se comença a aficar la forma [-i] ([ənásis], [ənásim], [ənásiw], [ənásin]); però entre la gent granada encara predomina la forma [ə] ([ənásəs], [ənásəm], [ə̀násəw], [ənásən]])" (BDLC, XII, 40).

d) Finalment, cal considerar l'existència de realitzacions comunes, és a dir, la coincidència que poden presentar les dues franges d'edat extremes, pel fet que el contrast l'experimenten els parlants lletrats o influïts per la pressió d'una variant dominant. Així, des d'un punt de vista morfològic, Alcover fa constar al BDLC (III, 357) la conservació, dins la comarca ripollesa $\mathrm{i}$ a la Vall de Ribes, per part de la gent vella, de la desinència en $-i$ de la primera persona del singular del present d'indicatiu dels verbs de la primera conjugació i el subjuntiu en -o. I justifica aquesta conservació tot dient: "Lo que succeeix qu'el dialecte barceloní ho ha envaït tot, especialment la gent una mica il-lustrada y correguda. Els vells, els infants i els analfabets, no estan de ple encara bax d'aquexa influència barcelonina". 
L'edat dels informadors és un dels factors socials que tenen més repercussió en la configuració dels usos lingüístics d'una comunitat pel fet que modifica les habituds socials i lingüístiques dels parlants. Alcover es decanta per a les seves enquestes per informants nens i adolescents, que, segons el seu parer, es troben lliures de prejudicis lingüístics, els quals són presents, en canvi, en els adults. Amb tot, aquesta variable no sempre actua ailladament, atès que pot covariar en funció del sexe o del nivell d'instrucció.

\section{La variable sexe}

Revisant les informacions que apareixen en el BDLC $i$ en els diversos quaderns de camp es constata que, pel que fa a les característiques dels informants entrevistats, tot $i$ que no existeix un rebuig explícit quant a la selecció de noies adolescents, la xifra total d'informants entrevistades és clarament inferior si es compara amb la dels nois adolescents. Tot fa pensar que Alcover les utilitzà com a informants quan no disposava d'altres subjectes que s'emmotllessin als criteris bàsics que havia establert.

La conveniència d'utilitzar dones en un treball d'investigació dialectològica es va prendre en consideració ja en les primeres etapes d'aquesta disciplina. A l'article publicat a Orbis, "Le lange des femmes: Enquête linguistique à l'echelle mondiale" (Merlo), es planteja el caràcter innovador o arcaitzant de la manera de parlar de les dones. Per bé que hi ha actituds contraposades en relació amb la seva tendència al conservadorisme o a la innovació, motivades de vegades per estudis dialectològics que partien de dades força impressionistes, subjectives i irregulars, sembla que es tendeix a acceptar que el sexe és més aviat un component de segona categoria en relació amb els resultats de l'enquesta. Així, són més significatius els factors socials que tenen a veure amb el tipus de vida que la dona desenvolupa en un lloc i els contactes socials que estableix com a conseqüència d'una mobilitat més o menys accentuada. Des d'un punt de vista sociolingüístic, s'ha confirmat també aquesta presumpció, de manera que en un nombre força important de casos, altres factors, com ara el nivell sociocultural $i$ l'estil, són les bases principals de la variació; ${ }^{7}$ el sexe, doncs, queda relegat a un segon pla. Tanmateix, s'han desenvolupat estudis -especialment de caràcter etnogràfic-que mostren que, en determinats aspectes, aquesta variable té una influència més clara que altres factors -per exemple, les dones solen ser més sensibles a les normes prestigioses que els homes. ${ }^{8}$

Chambers \& Trudgill (97-98) justifiquen la tendència de les dones

7 Vegeu Fasold (1990:223).

8 Vegeu Labov (1972:301-304). 
a seguir els models de prestigi a causa de l'absència d'un lloc destacat en la societat, la qual cosa motiva que hagin de marcar el seu estatus social mitjançant una conducta específica. Altres consideracions complementàries en relació amb aquesta tendència fan referència, d'una banda, a la manca de cohesió de les dones en les xarxes socials -la qual cosa les obliga a enfrontar-se més sovint a situacions de formalitat-i, d'una altra, a l'educació rebuda. Aquesta visió relativa al gènere sociocultural, que té a veure amb la dimensió sociocultural que adquireix l'individu socialitzat, s'oposa a sexe entès com a característica biològi$\mathrm{ca}$, que el subjecte adquireix des del primer moment de la concepció. Una visió intermèdia és defensada per Chambers (IO2), que sosté que les dones tenen unes habilitats verbals majors $\mathrm{i}$ millors que les dels homes, les quals poden sobrepassar les diferències de tipus sociocultural. Des d'aquesta perspectiva, la variabilitat basada en el sexe denota que les dones posseeixen una capacitat neurofisiològica verbal que es pot manifestar en forma de diferències sociolingüístiques. D'aquesta manera, les dones compten amb un repertori més ampli de variants o utilitzen uns recursos estilístics més rics que els homes que pertanyen als seus mateixos grups socials. Aquestes diferències es manifesten clarament en el lèxic $i$ en la pragmàtica i es constaten a través d'estudis relacionats amb l'anàlisi de la conversa i de la parla.

Per Alcover, la variable sexe no és un factor determinant, tot i que el nombre d'informants masculins supera amb escreix els femenins. Les noies, però, eren els subjectes preferits a causa del seu capteniment general, que contrasta amb la conducta juganera $\mathrm{i}$ indisciplinada dels nois. L'addició de les diverses dades numèriques aproximades que comptabilitzen els subjectes enquestats donen com a total absolut uns 901 informants enquestats, dels quals 194 són homes adults o vells, 25 dones adultes o velles, 568 nens o joves i II $_{4}$ nenes o noies. Alcover no considera les repercussions lingüístiques que pot suposar aquesta variable en la morfologia verbal. Per contra, en els casos en què les formes verbals s'obtenen a partir de les informacions subministrades per ambdós sexes, les dades resultants són sempre assimilades; en cap moment no són contrastades.

\section{La variable nivell d'instrucció}

Des d'un primer moment, els estudis d'Alcover - tant els que afectaven la morfologia com la fonètica- prenien com a base la resposta de subjectes illetrats o amb poca formació acadèmica. Pel que fa a la flexió verbal, els joves i adolescents seleccionats per Alcover es trobaven en tots els casos en procés de formació i, en termes quantitatius, el nombre d'anys dedicats a l'estudi depenia de la seva edat real. Tant la dialecto- 
logia com la sociolingüística han detectat que el nivell de formació educativa dels parlants determina clarament la variació lingüística. Aquest fet, òbviament, té repercussions directes en el canvi lingüístic.

En general, la variable nivell d'instrucció acostuma a restar inclosa entre els factors integrants de la classe social o del nivell sociocultural, a causa de la relació directament proporcional que s'estableix entre ambdues variables. Educació, professió, classe i estatus estan en efecte intimament imbricats.

Pel que fa a la fixació de límits entre els diversos nivells educatius, els estudis sociolingüístics poden partir de quatre categories generals: l'analfabetisme, l'ensenyament primari, l'ensenyament secundari i els estudis universitaris, tot $\hat{i}$ que altres propostes incideixen en delimitacions més particulars.?

Alcover fa diversos comentaris en relació amb les diferències existents entre la gent illetrada i la gent culta. A Gandia, com recull el $\mathrm{QC}_{2}$, "la - a darrere [ú] / [ó], sona -[o] o casi [-o]; darrere -á, - $e,-i$ sona $[-a]$ molt desmaiada o [-a] (o casi $[-0])$. N'hi ha que fan aqueix so més enfosquit que altres: com més poca cultura tenen més fosc la fan. La gent culta no ho fan tant". A Andorra, d'altra banda, fan el present de subjuntiu en $-o s,-o,-o n$ en la segona i tercera del singular i la tercera del plural, "però també existeix, entre la gent sense lletres, la forma $-e s,-e,-e n "$ (QCSchr). Altres modificacions fonètiques poden observar-se a Artà, on "la [-o] àtona final sona [-u] entre la gent analfabeta, i així diuen: [mistu], [moru], [rinxu], [kút fu] (porc)" (BDLC, XI, 39).

Les manifestacions fonètiques que caracteritzen una determinada varietat solen, en general, encobrir-se. Aixi, "la gent il.lustrada, els qui surten desiara de Felanitx, els qui volen parlar fi i s'amaguen de parlar felanitxer, en lloc de pronunciar tan de [ $\varepsilon]$, la rebaixen tant com poden i pronuncien [a], un so entre [E] i [a]: [astae kostipat], [un cae graes], [noj vaej maej] (no hi vaig mai), [un graen taep], [un pód do grae] (un poc de gra)" (BDLC, XI, 56).

Quant al nivell d'instrucció, doncs, Alcover seleccionava informants amb poca formació acadèmica, atès que era ben conscient que les dades de caràcter fonètic i morfològic obtingudes d'aquests subjectes presentaven unes determinades característiques diferenciadores que podien divergir de les que oferien els parlants cultes.

\section{La variable professió}

La professió és un dels factors que permet d'indicar la pertinença d'un individu a una classe social determinada, i esdevé, per tant, la variable

9 Vegeu López Morales (1983:27) i Samper (1990: 33-35). 
més lligada al concepte d'estatus. Com altres variables socials, l'ocupació influeix directament en la variació lingüística atès que la funció social que l'individu realitza en una comunitat està en relació directa amb la posició que ocupa en la jerarquia social i amb l'ús d'unes variants més o menys prestigioses i més o menys acostades a la norma.

Alcover deixa entreveure en algunes de les seves observacions la influència de determinats oficis -especialment els pagesos i els pescadors- sobre les solucions fonètiques i morfològiques que inclouen algunes respostes verbals.

Els pagesos poden presentar certes particularitats en la conjugació. Gelada (9I) indica que a Olot alguns pagesos diuen tòrnich, pòrtich, òbric, pòsich. $\mathrm{El} \mathrm{QC}_{4}$, en relació amb les formes verbals usades a Lleida, recull que els pagesos encara utilitzen les formes en [-gam], [-gaw] de subjuntiu. A Eivissa sembla que (BDLC, XII, 43) la pagesia elimina (com a Sant Mateu d'Aubarca) la [-2] si és precedida per [-i]: [pasiénsi], [dasgrási], [ráßi], [glóri], [aspési]; en canvi a la Vila mantenen la $[-\partial]$.

A Vinaròs existeix una vinculació clara entre professió i estatus social, pel que fa a la realització de la primera i tercera persones de l'imperfet d'indicatiu, "els pescadors i la gent baixa les fan acabar en [ávo], [áve], [ío] [íc] ([io anávo], tu [anáves], ell [anáve], (io m’ajup[io], tu t'ajup[ies], ell s'ajup[í])" (BDLC X, 209-2Io). Alcover, tot i que creu que es tracta d'un cas d'analogia amb la primera persona del singular del present dels verbs de la primera conjugació, que a Vinaròs és en [-o], relaciona aquestes oscil-lacions fonètiques amb l'ofici i amb la classe social. El mateix es pot dir que ocorre entre els pescadors i els pagesos: [io féo] tu [fées], ell [fée]; io [dújo], tu [dújes], ell [dúje] (BDLC, X, 210).

Una altra vinculació possible es pot manifestar també entre la variable professió i la variable edat. En relació amb Organyà, el QC4 esmenta: "per la conjugació pertany de ple al català occidental, oferint particularitats de la regió de la Seu d'Urgell. Les formes d'imperatiu i subjuntiu en [-gam] i [-gaw] i en indicatiu en [-am], [-aw] són característiques dels vells i pagesos".

Atès que hi ha una correlació evident entre l'exercici de determinades ocupacions i les realitzacions lingüístiques, és lògic de pensar que les solucions més prẹstigioses són preferides per les professions més prestigioses. Dins comunitats petites, malgrat que Alcover no ho considerà d'una manera explícita, seria possible distingir trets més o menys arcaïtzants o innovadors en la parla de persones que desenvolupen ocupacions diferents, com ara pagesos o pescadors. ${ }^{10}$ Per bé que el correlat esmentat queda reflectit en tots els nivells de lá llengua, cal 
pensar que l'acció d'aquesta variable té una incidència molt més remarcable en el lèxic que en qualsevol altre àmbit lingüístic.

\section{La variable procedència}

Medi rural i medi urbà contrasten actualment, i contrastaven encara més a començament de segle $\mathrm{XX}$ també des d'un punt de vista lingüístic. Al marge d'aquesta contraposició, Alcover veu les ciutats com una amenaça que pot difuminar les variants dialectals. Així, declara: "a Sant Climent, com a Sant Lluís, es Castell, Alaior, és la realització [é] de tota [á] tònica. La gent vella encara conserva la [á], el jovent tot se

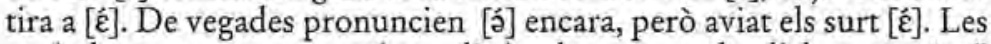
capitals tenen aquesta trista glòria de matar els dialectes veïns" (BDLC, XI, I88).

El contrast entre parlants rurals i parlants urbans s'evidencia tant en els quaderns de camp com en el BDLC. Així, a Gandia, segons el $\mathrm{QC}_{2}$, "els de la Ciutat, no els dels poblets veïnats, parlen apitxat; la [3] i la [j] les fan [t $\mathrm{t}]$ ]". D'altra banda, a Sant Lluís, Alcover detectà la introducció progressiva de la " $[\varepsilon]$ oberta, característica de Maó, en lloc de [á], característica del menorquí antic, que conserven prou els pagesos, mentre que les vilans se fan escolans d'amèn dels maonesos (BDLC, XI, 32)".

En altres casos, les observacions d'Alcover en relació amb l'àmbit urbà manifesten la influència que exerceixen Barcelona -especialment- o Perpinyà, com a grans nuclis de població, sobre les altres varietats frontereres $\mathrm{o}$, en el cas del barceloní, sobre altres àrees dialectals. És evident que aquesta influència no ve determinada únicament pel caràcter urbà sinó que s'hi associen factors extralingüístics, com ara el nivell d'instrucció, $o$ actituds lingüístiques, com el prestigi o l'autoestima. A Puigcerdà, per exemple, "entre els col-laboradors s'armen les grans discussions, sobre si tal forma o paraula són pròpies de Puigcerdà o dels altres pobles de la Cerdanya. Quasi sempre resulta que els que han estudiat $\mathrm{i}$ han sortit més sofreixen més viva la influència del dialecte barceloni" (BDLC, III, 283).

Pel que fa a les terres rosselloneses, la influència de Perpinyà era, segons Alcover, molt intensa: "Ben prompte trob aquí, respecte del llenguatge de Barcelona, lo metex que dins Catalunya francesa respecte del de Perpinyà, l'influència del dialecte de la capital demunt tots els núcleus de població, y especialment demunt les persones instruides, qu'aquí parlen just com a Barcelona. Les filles del Sr. Martí y els altres senyors sufrexen més aquella influència qu'En Blasi, qu'es un traballador; $n^{\prime}$ hi ha altres dos com ell, y se mantenen més cerdans del llenguarge. Si un no té en conte axò, s'esgarriarà d'una manera 
feresta en l'estudi del llenguatge parlat: segons amb qui parl, resultarà que dins tota Catalunya espanyola no hi ha cap altre dialecte qu'el barceloní, y dins la francesa cap altre qu'el perpinyanès: lo qual cosa és una mentida com un temple" (BDLC, III, 280).

\section{La variable classe social}

Les relacions que es poden establir entre llengua i característiques socials són més pròpies de la dialectologia urbana -amb la incorporació d'una dimensió social- que de la dialectologia tradicional, que tendeix a concentrar-se més aviat en la diferenciació espacial de la llengua.

El concepte de classe social, considerat en termes exclusivament econòmics, es basa en les teoritzacions de Karl Marx i Max Weber aplicades a l'estructura social $\mathrm{i}$ generades pel capitalisme industrial durant el segle XIX. Segons Marx, les classes s'estableixen en funció de la propietat del capital i dels mitjans de producció -la classe capitalista els posseeix, la classe proletària se'n troba desposseïda-; segons Weber, les classes responen a diferències de capital i es concreten en quatre: la classe proletària, la classe administrativa, els petits comerciants i la classe treballadora. L'estratificació social, des d'aquesta perspectiva, és un fenomen multidimensional en què actuen tres factors: la classe, l'estatus i el poder.

Posteriorment, la sociologia nord-americana introdueix la formació i la persistència d'estrats socials que depenen de les anomenades dimensions de l'estratificació; és a dir, de l'ocupació (el conjunt d'activitats de les quals resulten els ingressos econòmics), de la classe (una dimensió relacionada amb els ingressos, considerats com a mitjà de posseir objectes), de l'estatus (una dimensió social relativa a l'obtenció de respecte) i del poder (la capacitat de realitzar la voluntat d'un mateix, sovint per damunt de la dels altres).

Les propostes sociològiques que defineixen les classes des d'una perspectiva multidimensional consideren que no hi ha límits clars entre estrats, els quals no són més que categories ordenades al llarg d'un continuum. D'aquesta manera, els conflictes socials queden reduits al mínim pel fet que la societat és concebuda com un ens unitari on els individus comparteixen uns valors i unes mateixes normes de conducta i de prestigi.

La teoria sociolingüística treballa, en general, amb un model multidimensional d'estratificació social, que es pot definir a través d'unes categories -classe baixa, classe treballadora, classe mitjana-baixa, classe mitjana-alta-, ${ }^{\text {II }} \mathrm{i}$ amb uns índexs socioeconòmics -nivell d'instruc- 
ció, ocupació $\mathrm{i}$ ingressos- que permeten la classificació dels individus en funció del seu estatus social. Des d'aquesta perspectiva, cal tenir en compte que la distribució social dels usos lingüístics funciona, juntament amb altres variables esmentades, com un factor decisiu per al desenvolupament i l'expansió del canvi lingưístic.

Els factors que determinen la pertinença d'un individu a una certa classe social van ser considerats per Alcover només de manera indirecta i no els va atorgar cap paper preponderant en la recollida de dades verbals. Cal tenir en compte, però, el gran avenç que suposà per a la dialectologia catalana la utilització d'enquestes a través de qüestionaris més o menys sistematitzats, i en les quals es feien constar -com es reflecteix en les pàgines dels dietaris i dels quaderns de campla intervenció d'alguns d'aquests factors. No es pot oblidar que a començament de segle la dialectologia a Catalunya es trobava encara a les beceroles i, com tota disciplina en desenvolupament, havia d'experimentar necessàriament una evolució. Aquesta evolució s'ha concretat posteriorment en l'obertura cap a altres disciplines interrelacionades, com ara la geografia lingüística, la sociolingüística i, actualment, envers les anàlisis quantitatives computacionals.

\section{LES ACTITUDS LINGUÍSTIQUES}

L'actitud lingüística és una manifestació de l'actitud social de l'individu en relació amb la seva llengua i el seu ús. Existeix una relació estreta entre llengua $\mathrm{i}$ identitat, atès que aquesta darrèra permet de diferenciar un grup d'un altre. Es parla d'identitat linguística quan una comunitat es defineix per la varietat o varietats que utilitza, atès que l'ús lingüístic evidencia el que els parlants tenen de comú i de diferent.

Si les observacions anteriors d'Alcover esmentaven diversos aspectes relatius a les variables extralingüístiques que afecten les respostes dels informants i que tenen implicacions en el desenvolupament del canvi lingüístic, no es pot desestimar la informació que fa referència a les diverses actituds lingüístiques que podien presentar els subjectes enquestats i que s'estenen al llarg de dos pols oposats: des de la collaboració generosa $\mathrm{i}$ desinteressada a la incomprensió dels objectius de l'enquesta i al rebuig en la seva participació, passant en algunes ocasions per actituds que denoten una dosi elevada de prejudicis lingüístics, adoptats especialment per la gent culta. Altres actituds negatives es concentren en els mateixos joves enquestats: la indisciplina o la participació passiva en l'enquesta; i, encara, altres -l'autoestima, l'autoodi, la retracció-s'endevinen en els adults que hi van participar indirectament. 


\section{L'autoestima}

L'actitud lingüística descansa en la consciència lingüística; és a dir, en l'aparició de determinades actituds pel fet que els individus prenen consciència d'una sèrie de fets lingüístics que els afecten. Aquests fets poden pertànyer a la seva pròpia varietat, però també a altres varietats. Així, els parlants, en general, són conscients del que la seva comunitat prefereix, empren determinats usos lingüístics que els són propis i tenen la possibilitat de triar els que consideren més adients a les seves circumstàncies o interessos. Aquesta capacitat d'elecció és decisiva no només pel que fa a l'opció per una llengua en comunitats multilingües sinó en l'explicació dels fenòmens de variació i de canvi lingüístics.

$\mathrm{Al}$ marge de l'actitud, una de les conseqüències directes, pel que fa als parlants, de la presa de consciència lingüística és una conducta positiva - l'autoestima-o, en cas contrari, l'adopció de la posició contrària -l'autoodi. Altres conductes derivades de les actituds esmentades són la seguretat o la inseguretat lingüístiques.

En relació amb l'autoestima, des d'un punt de vista lingüístic, Alcover detectà sobretot en l'àmbit valencià una manca de consideració notable envers la llengua: "Pateixen els d'Elx del mateix mal que els de Monòver i els d'Alacant: estimen massa poc llur llengua; la tenen per no-res" (BDLC, X, 169).

Però la manca d'estimació vers la llengua no es registra només al País Valencià sinó també a la franja aragonesa: "Aquests catalans d'Aragó tenen una gran desgràcia: se tenen a manco parlar català, desprecien fondament la llengua pròpia, i se figuren, parlant castellà, tenir... la Seu plena d'ous, i no es volen dir catalans, sinó aragonesos. Pobra gent! És la manera infalible de romandre anul-lats i morts com a poble. Ningú hi anirà mai a aprendre el castellà de la barreja toixarruda i grollera que fan de les llengües, no parlant-ne bé cap" (BDLC, III, 326).

Tanmateix, no totes les actituds són negatives. Així, Alcover en troba també de positives: "La Sra. Mestra (de Tàrbena) (...) no ès com aquelles Mestres ni com aquells Mestres que treuen espires contra la nostra llengua i li fan una guerra a mort" (BDLC, $\mathrm{X}, 173$ ).

En relació amb l'amor a la llengua, els mots d'Alcover dirigits als algueresos són ben pessimistes: " $i$ Pobre català de l'Alguer! me’n duc el pressentiment de que tos fills no t'estimen més que com a medi casolà d'entendre's ells amb ells, per poder-se amagar dels forasters, de lo que diguen davant aqueis" (BDLC, VII, 35I). I conté una dubtosa prospectiva: "¿Quina sort està reservada an el català de l'Alguer? Els fills dels fills dels algueresos d'ara l'estimaran més que no aquests? Es mal de dir això. ¿Qui sab lo que succeïrà amb el temps? ¡Reserva ordinàriament tantes sorpreses el pervindre? Siguem optimistes sobre la futura sort del català de l'Alguer" (BDLC, VII, 351). 


\section{El prestigi}

El prestigi, que motiva que el parlant presenti actituds positives en relació amb la llengua, es pot considerar com un procés de concessió d'estima $\mathrm{i}$ de respecte envers els individus o grups que presenten certes característiques, i suposa la imitació del comportament i de les creences d'aquests individus o grups. El prestigi es pot mesurar des de dos punts de vista: com quelcom que es posseeix-conducta-o com quelcom que es concedeix -actitud.

Alcover declara en moltes ocasions l'acció preponderant de determinades varietats envers d'altres, les quals van perdent progressivament la seva fesomia particular. La penetració del barceloní, en un àmbit geogràfic determinat, o del dialecte de Perpinyà, en un altre, és conseqüència del prestigi que existeix al darrere d'aquestes varietats. El resultat d'aquesta actitud és l'adopció de trets, tant fonètics com morfològics, de la varietat dominant, la qual cosa motiva una propagació del canvi lingüístic.

La influència de Barcelona és constatada per Alcover sobre diverses localitats tant de les àrees oriental com occidental. Així, manifesta: "A Figueres és grossa la influència del dialecte barceloní" (BDLC, III, 363). I, pel que fa a l'àrea occidental: "Com que Tremp és la capital de la conca del seu nom $i$ de totes aquestes muntanyes $i$ està més en contacte amb Lleida i amb Barcelona, s'hi nota tot d'una una poderosa invasió del dialecte barceloní, que es manifesta preferentment en les persones de certa cultura i que han sortit de la població. Això fa que resulti una divergència entre el parlar dels nois i gent il-literata i el parlar d'aquelles altres persones, divergència que troben tot d'una entre la gent que hi tenen aplegada" (BDLC, III, 343).

La mateixa pressió es constata a la Seu d'Urgell: “...l'influència del parlar de Barcelona demunt la gent instruida y correguda; aquexa influència fa desaparèxer o recular a n-els llogarets arreconats les especialidats de llenguatge característiques d'aquexa regió, axò es, que la ' $e$ ' final (ə) sona com $e$ castellana, tan tancada (e), que passa a $i$ (maro $>$ mare $>$ mari, para $>$ pare $>$ pari; llibra $>$ llibre $>$ llibri; y fins y to en les formes verbals (el present y pretèrit imperfet d'indicatiu: ... tu miris, ell miri,... ells mirin; jo mirabi, mirabis, mirabi, miràbim,... mirabin). Aquí ja trobam el subjuntiu en $-o,-o s$ (volin ke jo bá jo, ke tu bá jos, k'ell bájo, k'ells báfon), qu'es troba dins tota la província de Lleyda, dins el Maestrat, a la Ribera d'Ebre y fins a Ripoll. Aquexes formes son fuytes molt de la ciutat de La Seu, pero's troben ben vives a Sant Miquel, parroquia d'aquí devora y per tots els poblets i viletes d'aquexa rodalia" (BDLC, III, 288).

Quant als aspectes morfològics, alguns parlants de Lleida manifesten ja a començament de segle la influència de Barcelona en la pro- 
núncia del subjuntiu en [-i], [-is], [-i], [-in] dels dialectes centrals i orientals, "però sols l'usen qualques presumits que volen fer lo parlar de Barcelona, escapollantse llur pròpia personalitat lingüística" (BDLC, X, 239).

A la Granadella, segons Alcover, es nota més que no pas a Lleida la invasió dels dialectes centrals, sobretot del barceloni; "aixi ès que els qui volen parlar polit, no usen casi may els subjuntius i els imperatius en $-o s,-o,-o n$, substituint-los p'el modern $-i,-i s,-i,-i n \circ \mathrm{p}^{3} \mathrm{el}-e s,-e$, $-e n "$ " BDLC, $\mathrm{X}, 240)$. Com es pot comprovar, aquesta influència repercuteix més poderosament en la gent lletrada i en la gent que es desplaça amb frequèència de la població.

L'influx de Perpinyà també es deixa sentir en terres rosselloneses. Així, a Prats de Molló, Alcover fa notar que “....alguns son gent de certa cultura [...] pero se ressenten un poch massa de l'influència llingüística de Perpinyà. Lo metex que Barcelona dins tota Catalunya espanyola, Perpinyà dins tota Catalunya francesa eczercex una gran influència llingüística, aficant y imposant per tot arreu la seua varietat dialectal" (BDLC, III, 264).

Naturalment, són innegables les repercussions lingüístiques d'aquesta influència: "y per lo mateix, axí com la gent culta de totes les nostres comarques d'assí dessă'ls Pirineus parlen com a Barcelona, allà dessà tota la gent que pretèn de cames primes, parlen com a Perpinyà. Hi ha que prevenir-se contra axò, per fer l'estudi de l'actualitat llingüística catalana. A n-el meu redol hi ha gent instruida $y$ alguns que no són sortits de Prats. Les demán les formes verbals y aquells les me donen idèntiques a les de Perpinyà; aquesys les me donen diferents, més acostades a n-el català d'Espanya. Aquells acaben per regonèxer que tambés diu lo que diuen aquests" (BDLC, II, 264). El mateix ocorre a Montlluís: "També trobam aquí polent l'influència del dialecte de Perpinyà, tant en els vells com a n-els minyons" (BDLC, III, 272).

\section{La retracció lingüîstica}

Com s'ha comentat anteriorment, les actituds lingüístiques s'actualitzen a través de conductes, que poden ser positives-d'acceptació de la pròpia varietat-o negatives - de refús. Alcover determinà certes actituds negatives que es manifesten a través de la negació o de la dissimulació de trets dialectals que en fan els informants de diverses localitats. Així, a la Granadella, el QC4 recull: "Lo subjuntiu en [-os], [-o], [-on] s'usa prou; però els qui volen parlar fi se'n retreuen perquè els externs se'n riuen". També a Alcalà de Xivert "... ja's troba lo subjuntiu en -os, $-o,-o n$ (canto, cantos, canto, canton); però se'n donen 
vergonya devant els esterns i se'n amaguen, si bé llavò los escapa (BDLC, X, 20r). A Son Servera "els serverins que volen dissimula llur accent fan [ae] (entre [a] clara i $[\varepsilon]$ oberta) ${ }^{{ }_{12}}$ (BDLC, XI, 37 ).

L'origen d'aquestes reaccions és la vergonya o la por al ridícul sobretot davant forasters o observadors externs. Alcover fa notar l: dificultat que suposa per al dialectòleg captar les veritables solucion: dialectals, i afirma: "És que un ha d'anar ben ulls espolsats per aglapi: les formes dialectals, perquè sovint els que les usen, se n'amaguen con si fossen un pecat" (BDLC, X, 237). I, més endavant, "Aquest fel demostra lo difícil que ès i malet de fer l'endardellar les formes especials de llenguatge d'una comarca, sobre tot si són molt especials i diferents de les ordinàries de les altres comarques, puys els nadius d'allà se n'amaguen d'emprarles devant els externs perquè no se'n riguen; i sovint, si un les ho demana, neguen com carreters, i devegades, si de cop descuyt los escapa qualque forma d'aqueixes, i un la consigna fentlosho notar, fins $\mathrm{i}$ tot s'enfaden. Ja ès necessari anar ben ulls espolsats per fer enquestes dialectals!” (BDLC, X, 24I).

\section{La incomprensió dels informants}

En general, es pot afirmar que la resposta dels informants al llarg de les diverses etapes d'enquestació fou positiva, tenint en compte, però, que l'entrevista amb infants $\mathrm{i}$ adolescents havia de comportar en la majoria dels casos un punt d'indisciplina i de cansament. Una altra actitud possible era la manca de comprensió dels objectius de l'enquesta, la qual cosa podia generar en els informants unes actituds de rebuig i de deserció. Alcover recull a través dels seus dietaris algunes d'aquestes experiències.

A Montlluís cap dels dos informants seleccionats "ni la vella ni la jove s'arriben a fer càrrech del nostre objectiu, $y$ al punt traslluim que feym nosa, encara qu'elles, fines com són, malavetjin amagarmosho" (BDLC, III, 27I).

En alguns casos, apareix la por al ridícul: "S'entrega'l Dr. Schädel per treure'n raca també ell. Aquella dona, l'estanquera, s'apura i acaba per dir-mos que mos en reym d'ella" (BDLC, III, 273-274). En d'altres, les enquestes fracassen a causa dels prejudicis dels informants, dels quals Alcover és ben conscient: "Són terribles els prejudicis de la gent culta en qüestió de dialectologia” (BDLC, X, I83).

A Pallerols, al llarg de l'eixida de 1906, Alcover entrevista el rector: "L'home s'asseu, escolta atent, y pren la paraula, dient que, a n-el seu

I2 Cal recordar que a Son Servera pronuncien [ęaé] la 'a' tònica. 
entendre, la llengua catalana se troba en una situació molt crítica, a punt de desaparèxer, de desferse, perque cada comarca pren p'el seu vent en matèria de llenguatge; hi introduexen mil corrupcions $\mathrm{i}$ adulteracions les més diferents y oposades, y que per lo metex aviat no n'hi haurà de llengua catalana. Bé hem fet per donarli a entendre que la cosa no va pels viaranys qu'ell se creu; que les divergències y particularitats dialectals hi son estades sempre, com son dins totes les altres llengues, y que la catalana es una de les que les presenta més petites, y per lo metex, una de les que's parlen menys fraccionades" (BDLC, III, 297). I a Montlluís: "Dins l'estanch hi devia haver dotze o tretze persones entre petits $\mathrm{i}$ grans, homes i dones. (...) entren dos senyors, un d'ells de Perpinyà, $\mathrm{y}$, com mos veuen, y s'enteren de lo que feym, el de Perpinyà mos diu: - Mais vustès, fent enraonar aquesta gent, trubaran pas lu veritable català. -És que no cercam, li dich jo, el veritable precisament, sinó el qu'es parla aquí, y tal com el parlen, no la gent de lletres, sino'ls qui no'n tenen cap.-Però, respon ell, aquí nu trubarán vustès qu'un patués, y el català és una llenga que té una gramàtica que la venen a Perpinyà y que la feren a Barcelona. -Però veu, li replich, ara per ara no mos interessa lo que diuen o venen a Perpinyà ni lo que han fet o dexat de fer a Barcelona, sino lo que parlen a Mont-lluís, y per això hi som venguts" (BDLC, III, 273-274). Però davant d'aquesta mena d'actituds, Alcover no té altra sortida que la retirada: "Aquell senyor s'escusa i... buyda, y nosaltres feym dos diners de lo metex, amb molt de greu de l'ànima de no poder treure tot aquex tresor lingüístic, tancat amb tants panys i forrellats dins aquella gent inabordable" (BDLC, III, 274).

\section{EL CONTACTE DE LLENGÜES}

La coexistència més o menys intensa de dues llengües en un territori origina fenòmens que afecten tots els nivells lingüístics. Aquest fet, en si mateix font de variació i de canvi, complementa tant els factors lingüístics interns generats per la dinàmica de la llengua mateixa com els factors extralingüístics, és a dir, la societat i el context. En parlar del contacte de llengües a Catalunya no es pot obviar la relació existent entre el català i el castellà. Els fenòmens lingüístics resultants d'aquesta interacció poden classificar-se en interferències, convergències, manlleus, calcs i alternances $i$, naturalment, afecten en un grau més elevat la llengua dominada que la dominadora.

Alcover, en relació amb l'acció del castellà, solament esmenta el que s'esdevé al País Valencià $i$ a les Illes, on es fa evident-sobretot a València-, iniciat el segle, una societat força castellanitzada, que es manifesta especialment en l'ús del castellà a les escoles (BDLC, X, 166) 
i en la predicació (BDLC, X, 178). Paral-lelament, es constata una actitud anticatalanista que ha perdurat fins als nostres dies: "Dins tot el Reyne de València segueix ben remolesta $i$ vitenca la prevenció i la betzèrria contra els catalanistes i fins i tot contra els catalans. Així ès que estich ben convençut de que les exageracions del catalanisme en matèria de llengua, que se manifesten sovint per vertader odi a la llengua castellana, lo qual els no catalans prenen per separatisme, ès en gran part la causa de que els valencians menin tanta de por a la restauració entre ells de la nostra llengua. N'estic convençut de que per fogir de lo que ells creuen separatisme dels catalans, cauen dins l'altre estrem de no volerse decantar del castellà ni deixar la predicació en castellà ni el catecisme en castellà, que constitueixen dues tremendes, dues ferestes, dues horribles aberracions i desorientacions dels valencians i de tota la gent de les comarques aragoneses que parlen catalá" (BDLC, XII, 333-334).

El castellà també penetra -amb intensitat diversa- en altres territoris catalans. Alcover, referint-se a Menorca i Eivissa, declara: "Una nota molt consoladora i encoratjadora de Menorca: que la castellanisació no hi du gayre força sobre tot en el poble, que se mantén prou aferrat a la seua llengua nadiua, molt més que el poble eyvissenc. Mentre a Eyvissa corren castellanismes a betzef, que escarrinxen les orelles de tot bon amador de la llengua nostra, a Menorca casi no n'hi ha per nat senyal, gràcies a Déu" (BDLC, XI, 34).

\section{DUES SITUACIONS PARTICULARS}

Els escrits d'Alcover constitueixen reculls succints d'informacions diverses que fan possible l'adquisició d'uns coneixements mínims en relació amb factors que poden incidir de manera directa o indirecta en el desenvolupament $i$ en els resultats de l'enquesta. En general, Alcover mai no ofereix una visió global d'un territori o d'una àrea dialectal determinada sinó que fa apreciacions particulars sobre algunes de les localitats visitades. Tanmateix, els dietaris recullen uns comentaris específics relatius a dos territoris de parla catalana que pertanyen administrativament $i$ políticament a altres estats: es tracta de la Catalunya Nord i de l'Alguer, que, actualment, passen per unes determinades situacions que aquest treball, per raons d'espai, no pot explicitar. ${ }^{13}$ Alcover, des de la seva òptica particular, en fa unes breus observacions i planteja una prospectiva no gaire falaguera.

13 Vegeu Marí (1992), per exemple, per a una visió succinta de la situació actual del català a la Catalunya Nord $i$ a l'Alguer. 


\section{El cas de la Catalunya Nord}

En primer lloc, es constata que la llengua utilitzada en aquest territori per adreçar-se a un foraster és el francès i que, davant d'ell, els nadius neguen parlar català. El 1906, durant l'eixida per l'àrea pirinenca oriental, acompanyat per Schädel, Alcover fa la crònica d'una de les enquestes: el rector de Montlluís ofereix per fer l'enquesta una senyora vella que està amb un parell de nétes i l'avi d'un dels escolanets, $\mathrm{Mr}$. Darro, membre principal de la Fabrique o Junta que té cura de les coses de l'església (.....) troben la vella dins la cuina amb una néta, "d'uns tretze anys, que comença per dirmos: Je ne sais pas parler catalan. Aqueixa sortida es obligada entre'l jovent fi d'aquexes terres. Amb tot $y$ axò, ells amb ells parlen catalá; devant un foraster, en francès" (BDLC, III, 27I).

Al marge d'aquesta primera actitud, Alcover aprecia la indiferència notable que els parlants de la Catalunya Nord senten envers el català: "Ja hu havia fet avinent a n-el Dr. Schädel, que, en entrar dins Catalunya espanyola, mudaria la cosa de sol a rel, s'acabaria aquella indiferència y fredor envers la llengua catalana que trobàvem per tot arreu dins Catalunya francesa, salves raríssimes escepcions, trobariem, casi per tot, entusiasme y fervor envers d'ella, y ja no toparíem en pus dificultats ni entrebanchs, p'els nostres estudis" (BDLC, III, 278).

En darrer terme, el canonge de Manacor no pot evitar una visió negativa pel que $\mathrm{fa}$ al futur de la llengua en aquest territori, que rectifica parcialment després d'una conversa amb un dels rectors entrevistats. Aquest s'empara en el manteniment del català a nivell familiar. Tanmateix, aquest fet no deixa de manifestar el tracte que rep el català com a llengua B en una situació clarament diglòssica. "Monsenyor Carsalade (...) me renya una micoya, perquè dins el Bolletí de juliol, rebut fa pochs dies, me demostr molt pessimista sobre'l pervindre del catalá de France. Monsenyor está en que no corre cap perill de desaparèxer, perque es encara el llenguatge qu'usen en família casi tots els catalans francesos, sobre tot els de fora Perpinyà, que són l'immensa majoria; $y$ amb tot y que dins l'escola fan parlar en francès els noys i les noyes, en sortir de l'escola no hi parlen pus, y sobre tot en dexar d'anarhi; y, si bé tots saben més o menys mastegar el francès, llur llengua usual és el català. Efectivament, es axí com diu Monsenyor, y m'hi adheresch, rectificant el judici esposat dins el dit Bolletí, com a resultat de la sèrie d'observacions fetes durant la present excursió (BDLC, III, 280)". 


\section{EI cas de l'Alguer}

La situació no és més favorable a l'Alguer. L’alguerès pateix la pressió de l'italià: "Ell (es refereix a Todesco) $m$ 'ha dit que li parlàs català; jo ho he fet, pero ell aviat $\mathrm{m}^{\text {'h }}$ a dit que comprenia que no era lo meteix sentir parlar algueresos que catalans: els algueresos han italianisada molt la pronuncia de llur català, i per això pe'ls italians son més bons d'entendre que no els catalans o balears" (BDLC, VII, 343). Per aquest motiu, Alcover utilitza habitualment l'italià per dirigir-se a Todesco: "A-les-hores he romput en italià, i en italià hem parlat sempre" (BDLC, VII, 343), i als mateixos algueresos: "En vista de la dificultat que he notada que tenien d'entendre' $m$, los parlava en italià quan els havía de dir res que fos necessari que ho entenguessin aviat i bé" (BDLC, VII, 348).

La pressió no prové només de l'italià sinó també dels dialectes sards. Així, "L'Alguer dins Sardenya és un illot lingüístic, vull dir, sols se parla català a Alguer; a les altres poblacions de Sardenya, fins les més acostades a Alguer, parlen dialectes sarts, sortits casi tots del llatí primitiu o invadits i saturats de llatinitat. De manera que el català d'Alguer du demunt les costelles dues grans influències: ra) la de l'italià literari; 2a) la dels dialectes sards, veinats de l'Alguer. Aquestes dues influències i l'aillament de Catalunya i de tot l'altre domini lingüístic català han obrat tan fort demunt el català d'Alguer, que li han donada una fesomia tota particular, que la allunya massa de totes les altres varietats catalanes, de tots els altres dialectes catalans" (BDLC, VII, 348).

L'alguerès, segons les observacions d'Alcover, desperta poc interès entre els mateixos parlants nadius: "En Juan Palomba, Mestre Públic d'Alguer, entusiasta del català, autor d'una Gramàtica de l'Alguerès, ben apreciable (...) En Palomba és l'únic o casi l'únic que es preocupa a l'Alguer de la sort del seu dialecte, és a dir, del català alguerès" (BDLC, VII, 348). La prospectiva és clarament negativa: "De manera que l'impressió que m'ha feta l'alguerès i el sentir els algueresos, es estada de tristor. La llengua l'he trobada massa decantada, massa distanciada dels altres dialectes catalans; i els algueresos els he trobats massa enamorats de l'italià, massa freds per llur nadiu llenguatge. Me tem molt que, fora d'En Palomba, no siguen ben re-de-poquets que'l vulguen per qualque cosa més que per parlar en família $i$ amb els amics per amagar-se dels forasters que no inspiren confiança" (BDLC, VII, 349). 


\section{LA VARIACIÓ I EL CANVI LINGÜISTIC}

Les pàgines anteriors han revisat diverses variables que contribueixen de manera directa a la variació lingüística i, més particularment, a la variació dialectal. ${ }^{14} \mathrm{La}$ variació dialectal és, doncs, el resultat d'un conjunt de corrents d'innovació lingüistica que s'estenen al llarg d'una àrea determinada. La relació entre variació i canvi lingüístic és estreta però no biunívoca. Així, mentre que no tota variació lingüística s'associa a un canvi, sí que tot canvi suposa la presència de variació lingüística.

El canvi lingüistic és, en realitat, un procés complex que depèn de factors de tipus social, geogràfic, psicològic i pragmàtic. Entre tots els factors que motiven o condicionen el canvi lingüístic potser els més comprovables són els que estan relacionats amb les condicions socials dels usos lingüístics. Alguns d'aquests factors ja han estat exemplificats al llarg de l'apartat dedicat a les variables sociolingüístiques. Cal afegir, però, el paper de les xarxes socials, que permeten de demostrar que la difusió de la innovació lingüística d'un grup social a un altre es produeix a través d'individus que estan vinculats a la xarxa mitjançant llaços febles. ${ }^{15}$ En efecte, els parlants que experimenten una major mobilitat acostumen a establir vincles més febles que els individus sedentaris i socialment més estables; d'aquesta manera acostumen a ser elements perifèrics del grup i per aquest motiu tenen més capacitat per difondre innovacions. ${ }^{\mathrm{I}}{ }^{\mathrm{C}}$

Alcover, des d'aquest perspectiva, destaca la importància de la permanència dels informants en la localitat d'origen amb vista a servar la varietat dialectal pròpia. Així indica que a Ponts: " $\mathrm{La} a$ - i la $e$ - (inicials) i la - $a-i$ la $-e$ - (medials) àtones, sonen casi com en castellá, però un poc desmaiades i enfosquides; poquíssim en boca dels infants i dels que no son sortits gens de Ponts; moltíssim en boca dels qui en són sortits molt" (BDLC, XI, 233). I a Sueca: "Tota - $a$ sona $[-\varepsilon]$ en boca de la gent tenral $i$ dels qui no son sortits de Sueca $i[-2]$ en boca dels qui en son sortits qualque poc" (BDLC, X, 189 ).

A aquests factors cal afegir els de tipus cronològic i generacional. Moll explicita en la introducció a La flexió verbal l'existència d'algunes formes verbals alternatives en poblacions que foren enquestades

$14 \mathrm{~A}$ més de les variables examinades, Francis ( $1983 ; 43$ ) afegeix la variable ètnia, que en aquest treball no és presa en consideració a causa de la seva manca d'incidència en els estudis dialectals d'Alcover.

15 Vegeu Milroy \& Milroy (1985: 339-384).

16 Vegeu a Wheeler (1993c: 69-77), en aquest sentit, l'aplicació al mallorquí de les relacions existents entre ús lingüistic $-\mathrm{i}$ les seves implicacions en la fonologia- $\mathrm{i}$ xarxa social. 
en dos períodes temporals distints. Des d'un punt de vista generacional, el mateix Alcover constata a través de les pàgines del $\mathrm{QC}_{5}$ que " $\mathrm{A}$ Manacor ja hi ha qualque diferència entre la meva pronúncia i de mos germans i la pronúncia de les meves nebodes".

Finalment, un altre factor que contribueix a la variació dialectal pot considerar-se des d'una perspectiva més àmplia, que afecta no només els individus sinó les localitats. Alcover evidencia que determinades zones són més susceptibles al canvi a causa de l'establiment d'uns majors contactes amb les localitats veïnes, els quals sovint es beneficien d'una facilitat en les comunicacions físiques: "Resulta que no hi ha grans diferències de llenguatge entre Sort i Esterri. N'hi haurà més amb els altres pobles de la Vall d'Àneu; és segur que en aquests $s$ 'hi conserva millor el dialecte de la vall que no a Esterri, per la major comunicació que té aquesta vila amb els altres centres de població externs" (BDLC, III, 309).

\section{CONCLUSIONS}

Són innegables les aportacions d'Alcover a la dialectologia catalana de començament de segle tant des del punt de vista de la recollida i tractament de les dades com des del punt de vista de la metodologia, amb la incorporació, com s'ha pogut comprovar, d'una incipient perspectiva sociolingüística. Alcover féu esment, per bé que no sempre de manera directa, de les variables socials que podien intervenir en la variació dialectal, les quals només van ser preses en consideració d'una manera efectiva en el moment de l'eclosió de la dialectologia amb un enfocament urbà.

Les dades exclusivament morfològiques de La flexió verbal estan envoltades d'un rerefons que abasta no sols els aspectes especifics relacionats amb el treball de camp i el procés de recollida de dades -elements propis de la geografia lingüística-, sinó també un conjunt de mecanismes que incideixen en graus diferents en la variació dialectal i en el canví lingüístic. La variació morfològica i fonològica, a més d'unes diferències motivades per la distància geogràfica, està subjecta sens dubte a uns condicionaments sociolingüístics. Aquest treball ha volgut considerar de més a la vora aquests factors i la seva possible influència en les dades que configuren La flexió verbal en els dialectes catalans.

MARIA PILAR PEREA UNIVERSITAT DE BARCELONA 


\section{REFERENCIES BIBLIOGRAFIQUES}

Alcover, A. M. "Escursió filológica de Mossen Alcover." Bolletí del Diccionari de la Llengua Catalana I (1902): 93-96.

Alcover, A. M. "Escursió filológica de Mossen Alcover." Bolletí del Diccionari de la Llengua Catalana I (I9O2): 97-Iio.

AlCOVER, A. M. "Varietats dialectals que presenta'l català. ¿S'han d'esvair, reduint-les a la uniformidat? ¿Hem de centralisar la llengua?" Bolletí del Diccionari de la Llengua Catalana I (1902-1903): 149-158. Alcover, A. M. "L'escursió amb el Dr. Schaedel." Bolletí del Diccionari de la Llengua Catalana III (I906-1907): 108-III.

Alcover, A. M. "Dietari de l'escursió filològica feta amb el Dr. Schädel dins els domini català, de 31 de juliol a I3 de setembre de 1906." Bolletí del Diccionari de la Llengua Catalana III (19061907): $257-367$.

Alcover, A. M. "Escorcolls dialectals." Bolletí del Diccionari de la Llengua Catalana III (1908): $17-24$.

Alcover, A. M. "Una mica d'exida filològica a Menorca i Eyvissa." Bolletí del Diccionari de la Llengua Catalana IV (1908): I85-189.

Alcover, A. M. "Una mica de dialectologia catalana." Bolleti del Diccionari de la Llengua Catalana IV (1908): 194-303.

Alcover, A. M. "Una altra mica d'eixida filològica." Bolletí del Diccionari de la Llengua Catalana IV (1908-1909): 3I4-316.

Alcover, A. M. "La nostra derrera eixida a l'estranger en referencia a la filología." Bolletí del Diccionari de la Llengua Catalana VII (I912-I9I3): 68-8I.

AlCOVER, A. M. “Dietari de l'Eixida d'enguany a França $i$ altres nacions per lo que's refereix a la filología romanista." Bolletí del Diccionari de la Llengua Catalana VII (1913): 309-356.

Alcover, A. M. "El parlar d'Eivissa i Formentera." Balletí del Diccionari de la Llengua Catalana VII (1913): 365-374.

Alcover, A. M. "Eixida filològica." Bolletí del Diccionari de la Llengua Catalana X (1918): $65-76$.

ALCOVER, A. M. "Dialectes catalans i llur estensió i característiques principals." Bolletí del Diccionari de la Llengua Catalana X (1918): 519-522.

Alcover, A. M. "Dietari de l'eixida p'el Reyne de València i Catalunya occidental (1918)." Bolletí del Diccionari de la Llengua Catalana X (1918): $165-252$.

AlCOVER, A. M. "Dues eixides filològiques que ens passà per malla donarne conte. Eixida a Eivissa i Formentera." Bolletí del Diccionari de la Llengua Catalana XI (1920): 23-28.

AlCOVER, A. M. "Dues eixides filològiques que ens passà per malla 
donarne conte, Eixida a Menorca." Bolletî del Diccionari de la Llengua Catalana XI (1920): 28-34.

Alcover, A. M. "La derrera eixida de conjugació i altres erbes a diferents pobles de Mallorca." Bolleti del Diccionari de la Llengua Catalana XI (1920): 34-59.

Alcover, A. M. "Una altra Eixida Filològica." Bolleti del Diccionari de la Llengua Catalana XI (1920): 182-184.

Alcover, A. M. "Dietari de l'Eixida filològica a diferents territoris de la nostra Llengua durant l'estiu d'enguany (1920)." Bolletí del Diccionari de la Llengua Catalana XI (1920): 185-336.

Alcover, A. M. "Més eixides filològiques. La conjugació i altres herbes de Tarrassa." Bolleti del Diccionari de la Llengua Catalana XII (192I): 18-26.

Alcover, A. M. "Més eixides filològiques. La conjugació i qualque cosa més del dialecte de Tamarit de Llitera." Bolletí del Diccionari de la Llengua Catalana XII (I92I): 26-30.

Alcover, A. M. "Més eixides filològiques. Escapada a Barcelona, Vallvidrera i Tarrassa." Bolletí del Diccionari de la Llengua Catalana XII (1921): 30-37.

Alcover, A. M. "Una altra eixida a Eyvissa." Bolleti del Diccionari de la Llengua Catalana XII (I92I): 37-44.

Alcover, A. M. "Els eyvissenchs. ¿Son o no nissaga catalana?" Bolleti del Diccionari de la Llengua Catalana XII (I921): 49-65.

Alcover, A. M. "Dietari de l'Eixida Filològica per tot Catalunya i e] Reyne de València de dia 26 de juny a 23 de novembre de 192r." Bolletí del Diccionari de la Llengua Catalana XII (I922): I45-335.

Alcover, A. M. "Escapades filològiques." Bolletí del Diccionari de la Llengua Catalana XII (1922): 339.

Alcover, A. M. Dietari de l'excursió filològica (1906) (ed. a cura de F. de B. Moll). Barcelona: Departament de Cultura de la Generalitat de Catalunya, 1983.

Alcover, A. M. Per la llengua (a cura de J. Massot i Muntaner). Palma i Barcelona: Secció de Filologia Catalana i Publicacions de l'Abadia de Montserrat, 1983.

Alcover, A. M. Diari de viatges (pròleg de J. Miralles). Mallorca: Moll, 1988.

Alcover, A. M. i Mol, , F. de B. La flexió verbal en els dialectes catalans. Barcelona: Anuari de l'Oficina Romànica (v. II (I929) [73] I[I84] II2, v. III (I930) [73] I- [168] 96, v. IV (I93I) [9] I- [104] 96, v. V (1932) [9] 2 - [72] 64), 1929-1933.

Alvar, M. Lengua y sociedad. Barcelona: Planeta, 1976.

CARIA, R. "L'alguerès des d'una perspectiva històrica" (ia part). Revista de l'Alguer I (1990): 33-53.

ChAMBERS, J. K. Sociolinguistic Therory. Oxford: Blackwell, 1995. 
Chambers, J. K. \& P. Trudgill. Dialectology. Cambridge: Cambridge University Press, 1980.

FASOLD, R. Sociolinguistics of Language. Oxford: Blackwell, 1990.

FrANCIS, W. N. Dialectology. An Introduction. London and New York: Longman, 1983.

GeladA, J. "Particularitats idiomàtiques d'Olot," Bolletí del Diccionari de la Llengua Catalana III (1906-1907): 91-94.

Labov, W. The Social Stratification of English in New York City. Washington, D.C.: Center for Applied Linguistics, 1966.

Labov, W. Sociolinguistic Patterns. Philadelphia: University of Pennsylvania Press, 1972.

LOPEZ MORALES, H. Estratificación social del español de San Juan de Puerto Rico. Mèxico: UNAM, 1983.

MARí, I. La llengua als països catalans. Barcelona: Fundació Jaume Bofill, 1992.

MERLO, C. "Le langage des femmes: Enquête linguistique à l'echelle mondiale." Orbis (1952): 12-13.

Mirroy, J. \& L. Milroy "Linguistic Change, Social Network and Speaker Innovation." Journal of Linguistics 21 (1996): 339-384.

Mol, F. de B. Un bome de combat (Mossèn Alcover). Mallorca: Moll, 1962 .

MORENO FERNÁNDEZ, F. Principios de sociolingüistica $i$ sociologia del lenguaje. Barcelona: Ariel, 1998.

PEREA, M.P. Complements a "La flexió verbal en els dialectes catalans". Dotze quaderns de camp d'Antoni M. Alcover. Barcelona: Curial edicions catalanes, Publicacions de l'Abadia de Montserrat, 1999.

PEREA, M.P. Compleció $i$ ordenació de "La flexió verbal en els dialectes catalans" d'A. M. Alcover i F. de B. Moll, Barcelona: Institut d'Estudis Catalans, I999.

PEREA, M.P. Estructura i variació en el verb català de començaments de segle. La flexió verbal en els dialectes catalans (Alcover-Moll). Tesi doctoral presentada al Departament de Filologia Catalana de la Universitat de Barcelona, 1999.

Petit, K. M. The Study of Dialect. London: Andre Deutsch, 1980.

PoP, S. La Dialectologie: aperçu bistorique et methodes d'enquêtes. 2 vols. Louvain: Chez l'Auteur, 1950.

ROMAINE, S. "The role of children in linguistic change". Language Change (Contributions to the Study of Its Causes), Trends in Linguistics 43. Ed. L. E. Breivik \& E. H. Jahr. Berlin, New York: Mouton de Gruyter, 1989.

Romaine, S. El lenguaje en la sociedad. Barcelona: Ariel, 1996.

Rotger, J. Don Antonio Maria. Palma de Mallorca: Publicación del "Círculo de Estudios", 1928. 
SAmper, J. A. Estudio sociolingüistico del español de Las Palmas de Gran Canaria. Las Palmas: La Caja de Canarias, 1983.

WHEELER, M.W. "El contacte, l'aillament i la tipologia dialectal". Actes del novè Col-loqui Internacional de Llengua $i$ Literatura Catalanes, Alacant-Elx, I99r. Vol. III, a cura de R. Alemany, A. Ferrando i L. B. Meseguer. Barcelona: Publicacions de l'Abadia de Montserrat, Universitat d'Alacant, Universitat de València, Universitat Jaume I, 1993. 